\title{
Reclaiming saline-sodic soils using electrochemical processes: a case study from Sahl El-Tina plain, Egypt
}

\begin{abstract}
A leaching experiment was conducted using column techniques assessing efficiency of electrochemical process to reclaim saline-sodic soils. Soil material was collected from Sahl El-Tina plain, which located in North West coast of Sinai, Egypt. The experiment was designed as factorial randomized complete block and all treatments were replicated three times. Two $2.5 \mathrm{~cm}$ diameter $\times 30 \mathrm{~cm}$ height mild stainless steel tubes were inserted into the soil matrix to serve as electrodes (i.e. cathode and anode). Distance between cathode and anode was $10 \mathrm{~cm}$. Electrodes were supplied by a direct current (DC) power supply; Volt ages of 0.3 or 9 Volt. Leaching was done using the intermittent method so as to add portions to the already saturated soil columns, and obtain leachates equal to the added portions. Pore volume $0.1 \mathrm{PV}$ was used in the leaching processes which are equal $498.4 \mathrm{~cm}^{3}$, i.e. PV being volume of pores per column, thus 1 PV equals volume of pores $\left(\mathrm{cm}^{3}\right)$ expressed as water quantity. Electric remediation increased ionic mobility and separated salts from soil. All treatments decreased soil EC and soil sodicity expressed as SAR and ESP. Results showed that 9 Volt treatment was more effective in decreasing the soil EC and soil sodicity than the other treatments. Efficiency of treatments were 9-Volt $>3$-Volt $>$ leaching alone (non-DC treatment). This study suggests that leaching using direct current (DC) led to improvement of the chemical properties of saline sodic soils and required a short time to reclaim saline-sodic soils compared with leaching alone.
\end{abstract}

Keywords: saline-sodic soils, salt-affected soils, soil reclamation, electrochemical remediation, leaching, Egypt

\section{INTRODUCTION}

Electrochemical remediation technology is part of a boarder class of technology known as direct current technologies. This technology uses an electric current in the treatment process to either mobilize or break down contaminants in soils or sediments (Niroumand et al. 2012). Jayasekera and Hall (2007) observed that the soil dispersion, otherwise known as soil sodicity (measured as exchangeable sodium percentage and sodium adsorption ratio) decreased by up to $90 \%$ in most regions of the soil between the electrodes. Electrokinetic restoration has successfully been used to increase ionic mobility and separate pollutants from soil fields (Acar and Alshawabkeh 1993; Acar et al. 1995; Zhou et al. 2005; Altaee et al. 2008; Ryu et al. 2009; Park et al. 2009; Kim et al. 2009a, 2009b; Baek et al. 2009). Salts have higher ionic mobility than heavy metals and many studies have been reported to remove and retain salts using the electrokinetic process (Eid et al. 2000a, 2000b; Manokararajah and Sri Ranjan 2005a, 2005b; Jia et al. 2005; Jia et al. 2006; Cho et al. 2009).

Electrokinetic restoration involves application of a low current or Volt age gradient between the electrodes installed at the contaminated site. Electromi- gration, namely the transportation of ions toward oppositely charged electrodes, is the major mechanism for separating and removing salts (Ryu et al. 2009). Electrokinetic process was performed by Cho et al. (2011) to restore sulfate-originated saline soil and to evaluate the effect of treatment duration, and found that after electrokinetic treatment, the electrical conductivity (EC) of the soil, an indicator of soil salinity, decreased to $1.93 \mathrm{dS} \cdot \mathrm{m}^{-1}$ from an initial value of $5.3 \mathrm{dS} \cdot \mathrm{m}^{-1}$ and the distribution of sulfate was similar to that of EC. By using column techniques the present study has been conducted to assess efficiency of electrochemical process to reclaim saline-sodic soils using. The main objective of this study was to evaluate the efficiency of leaching using direct current (DC) for remediation of saline-sodic soils in Egypt.

\section{MATERIALS AND METHODS}

$$
\text { Soil sampling }
$$

A leaching experiment was conducted using column techniques at the laboratory of Soil Science Department, Faculty of Agriculture, Zagazig University (Egypt) in 2012. The area from where the soil material was collected to conduct for the current column experiment was Sahl El-Tina plain located in North 
West coast of Sinai, Egypt. Soil material used for the experiment was collected from the top $30 \mathrm{~cm}$. Samples were air dried, crushed, mixed and passed through a $2 \mathrm{~mm}$ sieves. Table 1 shows physical and chemical properties of the saline-sodic soil.

\section{Soil columns design and preparation}

Nine polyvinyl chloride (PVC) cylindroids tubes of $40 \mathrm{~cm}$ height and $16 \mathrm{~cm}$ inside diameter were used. The bottom of each tube was sealed with perforated a mesh nylon screen and glass wool. Acid-washed inert sand (pre-washed with $\mathrm{HCl}$ and water) was placed on the tube bottom to make a $5 \mathrm{~cm}$ layer of the column. Soil was packed in tubes so that the soil column was $30 \mathrm{~cm}$ height and a bulk density of $1.4 \mathrm{Mg} \cdot \mathrm{m}^{-3}$. This required a quantity of soil of $8 \mathrm{~kg}$ of soil per column. Such arrangement allowed to give sufficient space (5 $\mathrm{cm}$ on top of soil column) for addition of water for the leaching process. Figure 1 illustrates a schematic drawing of the electric cell used in this study. Two

TABLE 1. Physical and chemical properties of studied soil

\begin{tabular}{|c|c|}
\hline Property & Value \\
\hline $\begin{array}{l}\text { Particle size distribution [\%]: } \\
\text { - Clay } \\
\text { - Silt } \\
\text { - Fine sand } \\
\text { - Coarse sand } \\
\text { - Texture class }\end{array}$ & $\begin{array}{c}46.5 \\
35.2 \\
15.6 \\
2.7 \\
\text { Clayey }\end{array}$ \\
\hline $\begin{array}{l}\text { Soil moisture characteristics [\%]: } \\
\text { - Saturation percent } \\
\text { - Field capacity } \\
\text { - Wilting point }\end{array}$ & $\begin{array}{l}62.3 \\
31.2 \\
15.6 \\
\end{array}$ \\
\hline 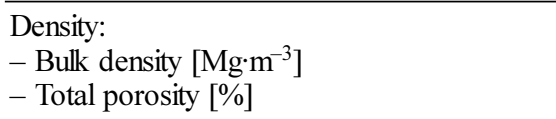 & $\begin{array}{c}1.4 \\
49.1\end{array}$ \\
\hline $\begin{array}{l}\text { Organic matter }\left[\mathrm{g}^{\mathrm{kg}}{ }^{-1}\right] \\
\mathrm{CaCO}_{3}\left[\mathrm{~g} \cdot \mathrm{kg}^{-1}\right]\end{array}$ & $\begin{array}{l}5.3 \\
94 \\
\end{array}$ \\
\hline pH [soil suspension $1: 2.5]$ & 8.6 \\
\hline 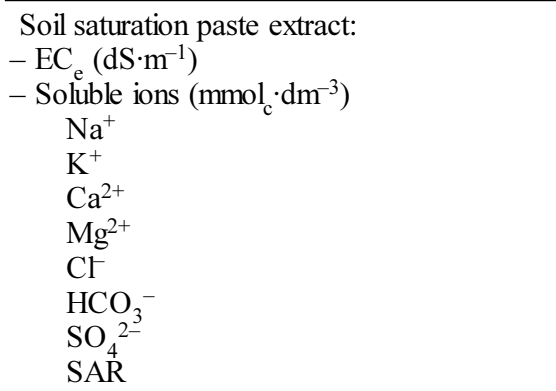 & $\begin{array}{c}51.2 \\
\\
589 \\
26.4 \\
152 \\
564 \\
1126 \\
9.7 \\
195 \\
31.0\end{array}$ \\
\hline $\begin{array}{l}\text { Exchangeable cations and CEC }\left(\mathrm{cmol}_{\mathrm{c}} \cdot \mathrm{kg}^{-1}\right) \text { : } \\
\mathrm{Na}^{+} \\
\mathrm{K}^{+} \\
\mathrm{Ca}^{2+} \\
\mathrm{Mg}^{2+} \\
\text { CEC }\left(\mathrm{cmol}_{\mathrm{c}} \cdot \mathrm{kg}^{-1}\right) \\
\text { ESP }\end{array}$ & $\begin{array}{c}11.3 \\
2.8 \\
7.4 \\
10.0 \\
31.5 \\
35.9\end{array}$ \\
\hline
\end{tabular}

FIGURE 1. Schematic drawing of the soil column and electrochemical experimental system

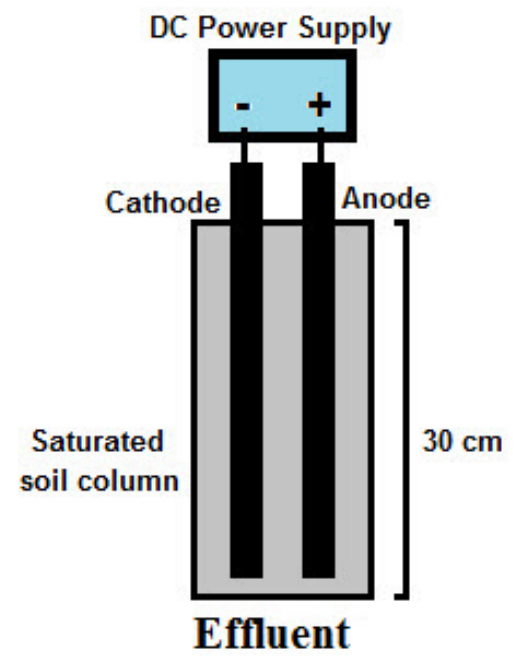

$2.5 \mathrm{~cm}$ diameter $\times 30 \mathrm{~cm}$ height mild steel tubes were inserted on the soil matrix to serve as electrodes (i.e. cathode and anode). Distance between cathode and anode was $10 \mathrm{~cm}$. Electrodes were contacted to a direct current power supply (DC). The voltage treatments were 3 and $9 \mathrm{~V}$. An additional treatment using no electric treatment was conducted. In this treatments water having EC $1.5 \mathrm{dS} \cdot \mathrm{m}^{-1}$ was used for the leaching.

\section{Leaching process}

The leaching procedure was conducted using the intermittent method adding water portions to the already saturated soil columns. Leachates were collected until obtaining volume equals to the one added. Portions of 0.1 pore volume $(\mathrm{PV})$ were used in the leaching processes. The PV equals $4984 \mathrm{~cm}^{3}$ (i.e. volume of pores per column). The water was added in increments. Leachates were collected and analyzed for salinity. Leaching termination was done after passing $1 \mathrm{PV}$ through soil columns (i.e. ten increments of $0.1 \mathrm{PV}$ ). Each leachate was analyzed for the total soluble salts and soluble ions.

\section{Methods used for analysis}

After the termination of leaching, soil columns were separated into two segments as follows: $0-15$ and $15-30 \mathrm{~cm}$. Soil from each segment was air dried, crushed, mixed and passed through a $2 \mathrm{~mm}$ sieves and analyzed according to the methods described by Richards (1954) and van Reeuvijk (2002).

- Particle size distribution was determined according to the pipette method. Sodium hexametaphosphate was used for dispersion after leaching the soluble salts.

- Calcium carbonate content was determined using the calcimeter. 
- Organic matter content was determined using Walkley-Black method.

- Electric conductivity $\left(\mathrm{EC}_{\mathrm{e}}\right)$ and the main ion composition were determined in the saturation soilpaste extract as follows:

$1-\mathrm{EC}$ by conductometric method.

$2-\mathrm{CO}_{3}^{2-}$ and $\mathrm{HCO}_{3}^{-}$content by titration with a standard solution of sulphuric acid using phenolphthalein as an indicator for former and methyl orange for latter.

$3-\mathrm{Cl}^{-}$content by argentometric method.

$4-\mathrm{Ca}^{2+}$ and $\mathrm{Mg}^{2+}$ content were determined by titration with sodium versinate solution

$5-\mathrm{Na}^{+}$and $\mathrm{K}^{+}$content using flame photometer.

- The $\mathrm{pH}$ value was measured using a $\mathrm{pH}$-meter in soil suspension 1:2.5.

- Cation exchange capacity and exchangeable cations were determined by $1 \mathrm{M}$ ammonium acetate extraction at $\mathrm{pH} 7$.

\section{RESULTS AND DISCUSSION}

\section{Chemical composition of leachates}

Salt and ion removal as affected by leaching and electric treatments are shown in Figure 2. Generally, results show that all treatments receiving direct current (DC) gave greater salt removal. Salt removal by treatments was in the following order: 9 -Volt $>3$-Volt $>$ leaching alone (i.e. non-DC). The main effect shows that 9 Volt gave the highest salt removal $\left(49.5 \mathrm{dS} \cdot \mathrm{m}^{-1}\right)$ whereas non-DC treatment gave the lowest $(38.2$ $\left.\mathrm{dS} \cdot \mathrm{m}^{-1}\right)$. This shows the high efficiency of electric current in salt removal from saline sodic soils. At start of leaching and after collection of first leachate, the EC values of the leachates were 187, 178 and 210 $\mathrm{dS} \cdot \mathrm{m}^{-1}$ for the 3,9 Volt and the non-DC, respectively. For the second and third leachates, the DC-treatments were of markedly greater efficiency in removing salts. The 3 Volt and 9 Volt treatments surpassed the non-DC treatment by 13 to $46 \%$ for the 3 Volt and 28 to $79 \%$ for the 9 Volt. From the fourth leachate onwards, both DC-treatments maintained their superiority, though by smaller margins. Imposition of electrical field in such soil of low permeability causes ions to move towards electrode of opposite. It follows that most of the readily soluble salts, originally present in the soil, were leached out with the leachate. Such mechanism was considerable during the first 3 leachates and decreased sharply afterwards. Athmer et al. (2013) reported that a series of anode and cathode wells placed in the soil can be used to separate and remove chloride $\left(\mathrm{Cl}^{-}\right)$and sodium $\left(\mathrm{Na}^{+}\right)$, respectively. Clear from the results that the higher electric current, the more decomposition of salts and therefore it was easier to leach ions from the soil. Similar results have been

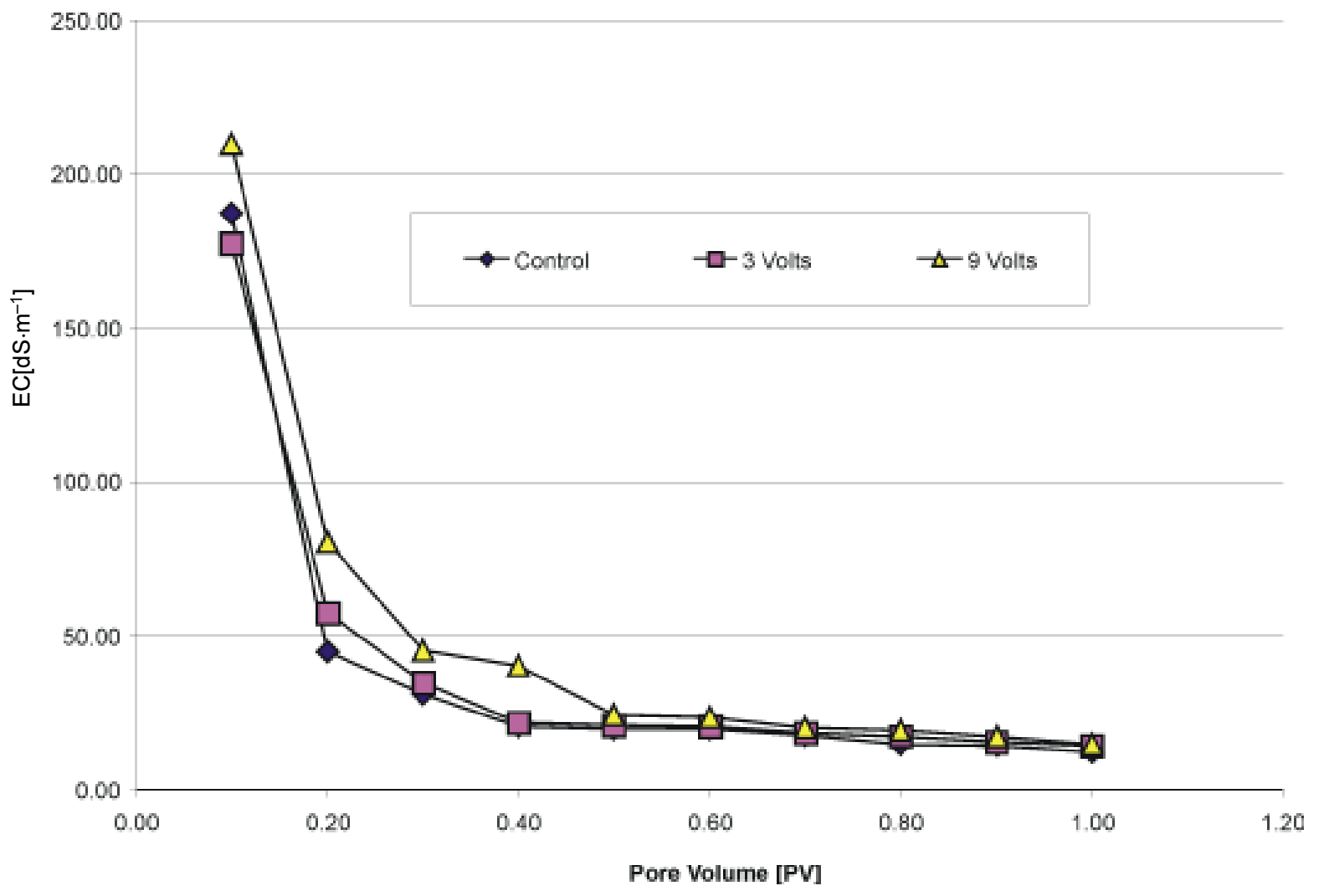

FIGURE 2. Change on $\mathrm{EC}$ of the leachate as a function of pore volume 
reported by others authors (Park et al. 2009; Kim et al. 2009a, 2009b; Baek et al. 2009; Altaee et al. 2008; Zhou et al. 2005; Acar and Alshawabkeh 1993; Acar et al. 1995).

\section{Soil salinity}

Soil salinity as affected by leaching and electric treatments is shown in Table 2. Data reveal the effect of treatments throughout the depth of soil columns was significantly. Also the interaction between treatments and depth of soil was statistically significant. Soil EC was decreasing upon leaching in all depths. The results revealed that, salinity of soil was significantly decreased by 9 Volt and 3 Volt treatments compared with control in the two depths. The efficiency in decreasing soil salinity was higher with 9 Volt than 3 Volt treatments and lowest with the non-DC treatment. Salinity relative to initial status decreased by 94, 76 and $73 \%$ due to 9 Volt, 3 Volt and non-DC treatments, respectively. The pattern of rating regarding the treatments was similar in each of the two soil depths. In general, there was greater salinity with soil depth. You-Jin et al. (2013) reported that the soil EC was reduced $56 \%$ using electrokinetic direct current (DC). Commonly, when a Volt age gradient is applied to a soil, the resulting current flowing is found to be decreasing with time after an initial period of increase, which may last for several hours (Virkutyte et al. 2002; Kim et al. 2005; Lynch et al. 2007). In fact, the initial current increase is due to an increase in the salt concentration in the soil pore water, due to the salt dissolution from soil particles (Mitchell 1993). As time elapses, the pore water ionic concentration decreases due to the gradual depletion of solutes, to the precipitation of non-conductive solids from the pore water salts and the polarization of the electrodes (Acar and Alshawabkeh 1993; Acar et al. 1995; Yu and Neretnieks 1997; Virkutyte et al. 2002; Reddy and Chinthamreddy 2004; De Gioannis et al. 2007; Lynch et al. 2007). In particular, during the unenhanced electrochemical treatment, the current flowing is gradually decreased because of the formation of high electric resistivity zone near the cathode, due to the precipitation of metal hydroxides under the local basic conditions (Acar et al. 1995; Amrate et al. 2005; Kim et al. 2006). Therefore, it is common for the current to reduce with time, unless amendments, such as ionic solutions, are supplied to provide new charge carriers in the soil-solution system (Reddy and Chinthamreddy 2004). Usually, in bench-scale electrokinetic tests, the electrical currents are found to increase rapidly after the application of the Volt age gradient, to reach a peak value within 1-24 $\mathrm{h}$, and then to decrease and stabilized at a nearly constant steady state value (Reddy and Chinthamreddy 2004; Kim et al. 2005). Various salts can contribute to the ionic conductivity of the pore water solution. $\mathrm{HCO}_{3}{ }^{-}$and $\mathrm{CO}_{3}{ }^{2-}$ may be released from soil. The addition of ionic solutions (e.g. $\mathrm{NaCl}, \mathrm{H}_{2} \mathrm{SO}_{4}$ ) can allow for an additional salt release and improve the soil conductivity. Also the addition of hydrogen peroxide could enhance the ionic conductivity, by providing anions deriving from its decomposition, such

TABLE 2. Chemical soil properties of soil at the end of leaching

\begin{tabular}{|c|c|c|c|c|c|c|c|c|c|c|c|c|c|}
\hline \multirow{2}{*}{$\begin{array}{l}\text { Treatment } \\
\text { (A) }\end{array}$} & \multirow{2}{*}{$\begin{array}{l}\text { SD } \\
\text { (B) }\end{array}$} & \multirow{2}{*}{$\begin{array}{l}\mathrm{EC} \mathrm{e}_{\mathrm{e}} \\
\mathrm{dS} \cdot \mathrm{m}^{-1}\end{array}$} & \multirow[t]{2}{*}{$\mathrm{pH}$} & \multicolumn{4}{|c|}{ Cations $\left(\mathrm{mmol}_{\mathrm{c}} \cdot \mathrm{dm}^{-3}\right)$} & \multicolumn{4}{|c|}{ Anions $\left(\mathrm{mmol}_{\mathrm{c}} \cdot \mathrm{dm}^{-3}\right)$} & \multirow[t]{2}{*}{ SAR } & \multirow[t]{2}{*}{ ESP } \\
\hline & & & & $\mathrm{Na}^{+}$ & $\mathrm{K}^{+}$ & $\mathrm{Ca}^{2+}$ & $\mathrm{Mg}^{2+}$ & $\mathrm{Cl}$ & $\mathrm{HCO}_{3}^{-}$ & $\mathrm{CO}_{3}{ }^{2-}$ & $\mathrm{SO}_{4}^{2-}$ & & \\
\hline \multirow{3}{*}{$\begin{array}{l}\text { Leaching alone } \\
\text { (non-DC) }\end{array}$} & $0-15$ & 13.9 & 8.1 & 78.3 & 4.3 & 17.0 & 53.0 & 87.7 & 14.1 & 7.1 & 43.6 & 13.2 & 19.4 \\
\hline & $15-30$ & 14.0 & 8.0 & 57.5 & 4.2 & 36.5 & 55.7 & 57.7 & 28.6 & 14.4 & 53.3 & 8.5 & 14.1 \\
\hline & Mean & 13.9 & 8.1 & 67.9 & 4.2 & 26.7 & 54.3 & 72.7 & 21.3 & 10.7 & 48.4 & 10.9 & 16.8 \\
\hline \multirow[t]{3}{*}{ 3-Volt } & $0-15$ & 12.2 & 8.0 & 50.9 & 3.6 & 31.0 & 48.4 & 52.4 & 35.9 & 18.0 & 27.5 & 8.1 & 13.6 \\
\hline & $15-30$ & 12.5 & 8.2 & 41.1 & 3.7 & 43.6 & 48.6 & 49.0 & 19.9 & 10.0 & 57.9 & 6.6 & 11.8 \\
\hline & Mean & 12.4 & 8.1 & 46.0 & 3.6 & 37.3 & 48.5 & 50.7 & 27.9 & 14.0 & 42.7 & 7.3 & 12.7 \\
\hline \multirow[t]{3}{*}{ 9-Volt } & $0-15$ & 2.8 & 8.0 & 24.0 & 1.8 & 16.6 & 23.8 & 22.3 & 10.4 & 5.2 & 28.2 & 3.7 & 8.0 \\
\hline & $15-30$ & 3.0 & 7.9 & 11.1 & 0.8 & 6.6 & 10.5 & 12.4 & 5.0 & 2.5 & 9.1 & 3.9 & 8.3 \\
\hline & Mean & 2.9 & 7.9 & 17.6 & 1.3 & 11.6 & 17.1 & 17.4 & 7.7 & 3.9 & 18.7 & 3.8 & 8.1 \\
\hline \multicolumn{14}{|c|}{ Means of soil depth (B) } \\
\hline \multirow[t]{3}{*}{ Soil Depth $(\mathrm{cm})$} & $0-15$ & 9.6 & 8.0 & 51.0 & 3.2 & 21.5 & 41.7 & 54.2 & 20.1 & 10.1 & 33.1 & 8.3 & 13.7 \\
\hline & $15-30$ & 9.8 & 8.0 & 36.6 & 2.9 & 28.9 & 38.2 & 39.7 & 17.8 & 9.0 & 40.1 & 6.3 & 11.4 \\
\hline & Mean & 9.7 & 8.0 & 43.8 & 3.0 & 25.2 & 40.0 & 46.9 & 19.0 & 9.5 & 36.6 & 7.3 & 12.5 \\
\hline \multirow[t]{3}{*}{ LSD 0.05} & A & 0.24 & NS & 3.61 & 0.20 & 2.65 & 3.20 & 8.06 & 4.72 & 2.37 & 13.11 & 0.75 & 0.86 \\
\hline & B & 0.20 & NS & 2.95 & NS & 2.17 & NS & 6.58 & NS & NS & 10.70 & 0.61 & 0.70 \\
\hline & $\mathrm{AB}$ & 0.34 & NS & 5.11 & NS & 3.75 & NS & 11.39 & 6.68 & 3.35 & 18.54 & 1.06 & 1.21 \\
\hline
\end{tabular}

Notes: SD - soil depth $(\mathrm{cm}) ; \mathrm{EC}_{\mathrm{e}}$ - electrical conductivity; $\mathrm{pH}$ was measured in soil suspension 1:2.5; SAR - sodium adsorption ratio; ESP exchangeable sodium percentage; $\mathrm{A}$ : - treatments, $\mathrm{B}$ - soil depth and $\mathrm{AB}$ - interaction between treatments and soil depth. 


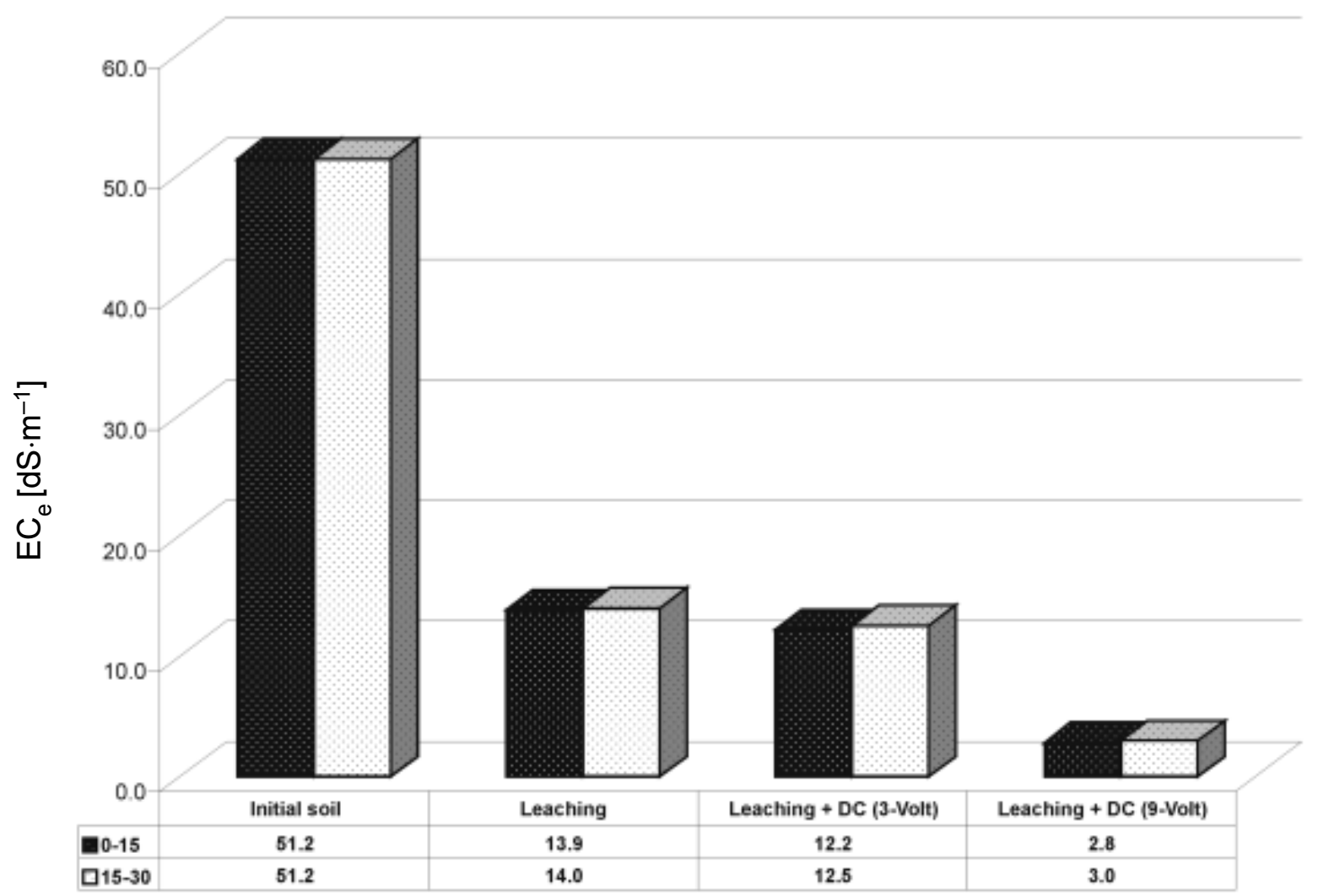

FIGURE 3. $\mathrm{EC}_{\mathrm{e}}$ in the soil segments after termination of experiment

as $\mathrm{O}_{2}^{-}$and $\mathrm{HO}_{2}^{-}$(Kim et al. 2006). In the electrokinetic processes, the decrease in the current flowing may be counterbalanced by the addition of proper ionic solutions as the electrodes, to compensate the exhaustion rate of the electrolyte solution by electromigration (Park et al. 2005). These processes are designed in order to balance the ionic extraction rate due to electromigration and the supplementation of salts in the electrolyte solution, therefore the resulting current may be constant.

\section{Soil $\mathrm{pH}$}

Electrolysis of the water, under the applied Volt age caused a change in $\mathrm{pH}$. Reactions can be described as follows:

At anode (oxidation): $2 \mathrm{H}_{2} \mathrm{O} \rightarrow \mathrm{O}_{2 \text { (gas) }}+4 \mathrm{H}^{+}$(aq) $+4 \mathrm{e}^{-}$ At cathode (reduction): $4 \mathrm{H}_{2} \mathrm{O}+4 \mathrm{e}^{-} \rightarrow 2 \mathrm{H}_{2 \text { (gas) }}+4 \mathrm{OH}^{-}$(aq)

Hydrogen and hydroxide ions generated at the anode and cathode were transported toward the opposite charged electrodes by electromigration. Thus, soil $\mathrm{pH}$ would decrease at the anode and increase at the cathode. Results of $\mathrm{pH}$ are presented in Table 2 and Figure 4. Results reveal that there was no significance between all treatments. The interaction between treatments and depth of soil were not significant as well. There was a tendency for a decrease in $\mathrm{pH}$ values due to treatments of electric remediation. The $\mathrm{pH}$ values ranged from 8.0 to 8.2 (Fig. 4). The soil must have had high buffering capacity due to the heavy clayey texture and high $\mathrm{CaCO}_{3}$ content (Table 1). Kim et al. (2011) observed that the $\mathrm{pH}$ values ranged from 4.8 to 6.6 due to the high buffering capacity of the soil upon high organic content and considerable silt content.

\section{Soil sodicity}

Sodium adsorption ratio (SAR) and exchangeable sodium percentage (ESP) were estimated by using the following equation where ionic concentration of the saturation extracts are expressed in $\mathrm{mmol}_{\mathrm{c}} \cdot \mathrm{dm}^{-3}$

$$
\begin{gathered}
S A R=\frac{N a}{\sqrt{\frac{C a+M g}{2}}} \\
E S P=\frac{100(-0.0126+0.01475 \times S A R)}{1+(-0.0126+0.01475 \times S A R)}
\end{gathered}
$$




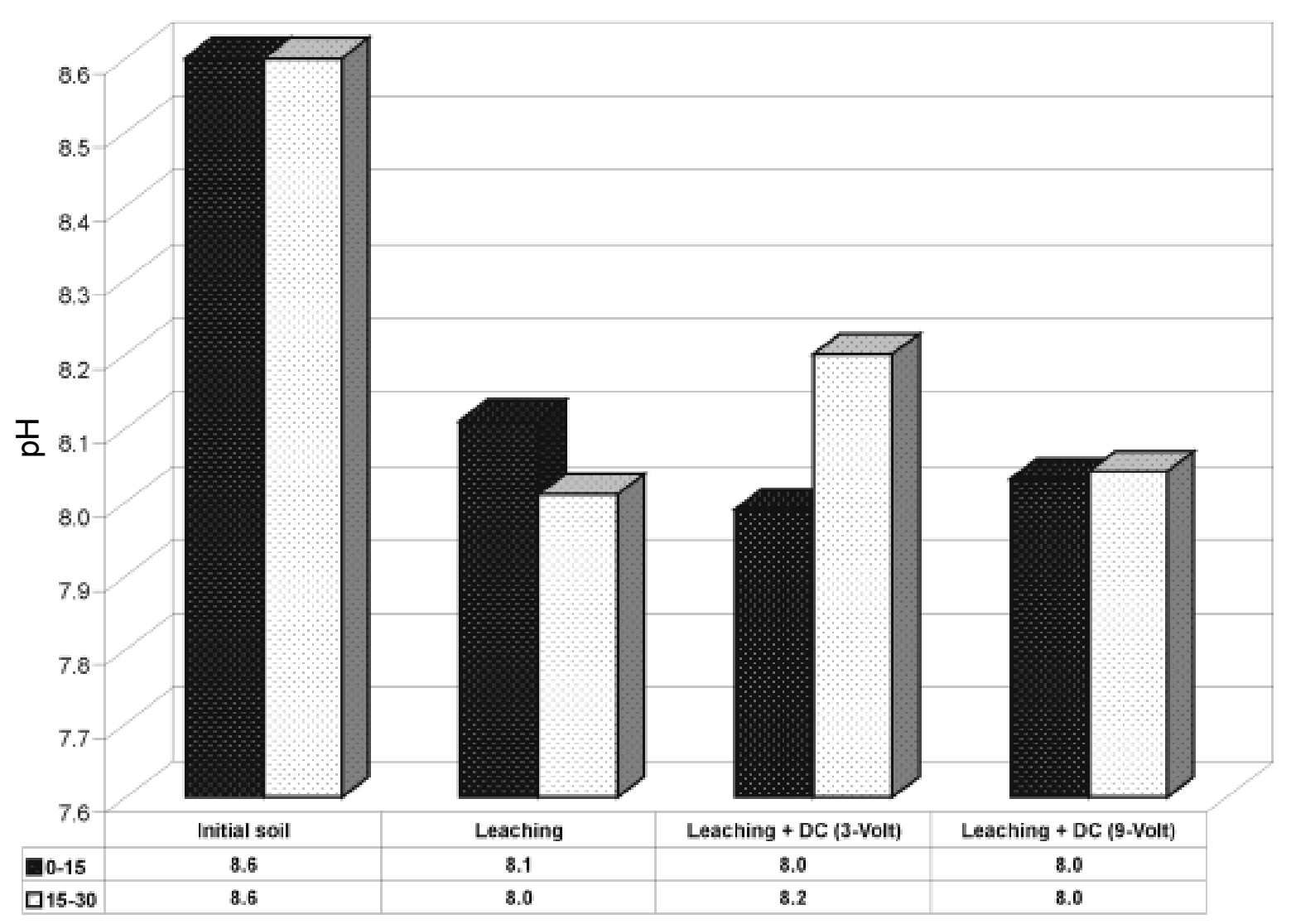

FIGURE 4. $\mathrm{pH}$ in the soil segments after termination of experiment

The results of ESP and SAR are presented in Table 2, and Figs. 5 and 6 . The decrease of sodicity upon leaching is shown by very high decrease in SAR (being ranging from less than 1 to 13 compared with 31 before leaching) and also very high decrease in ESP (being less than 1 to 19 as compared with about 36 before leaching). The comparative efficiency rating of treatments is as follows: 9 Volt $>3$ Volt $>$ leaching alone (i.e. non-DC). The decrease in soil SAR upon leaching amounted to $65.0,76.5$ and $87.5 \%$, for the non-DC, 3-Volt and 9-Volt treatments, respectively. Regarding ESP, respective decreases were $53.2,64.6$ and $76.9 \%$ for the non-DC, 3 Volt and 9 Volt treatments, respectively. The pattern of rating regarding the treatments was similar in each of the two soil depths. In general there was a greater ESP and SAR value with soil depth. The results showed that sodicity of soil significantly decreased by 9 Volt and 3 Volt treatments compared with control in the two depths. This may be explained by soluble ions removal process by leaching which makes it easy for exchangeable sodium ions released from the exchange complex to the soil solution upon equilibrium between soluble and exchangeable ions and then the removal of exchangeable ions become easier. Also, presence of calcium carbonate could be helpful in reducing ESP of the soil columns.

\section{CONCLUSIONS}

A leaching experiment was conducted using column techniques assessing efficiency of electrochemical process to reclaim saline-sodic soils. All treatments significantly decreased soil EC, $\mathrm{pH}$ and soil sodicity expressed as SAR and ESP. Efficiency of treatments was in the following order: 9-Volt $>3$-Volt $>$ leaching alone (non-DC treatment). Leaching using direct current (DC) led to improvement of the chemical properties of saline sodic soils and required a shorter time to reclaim saline-sodic soils comparing with leaching. 


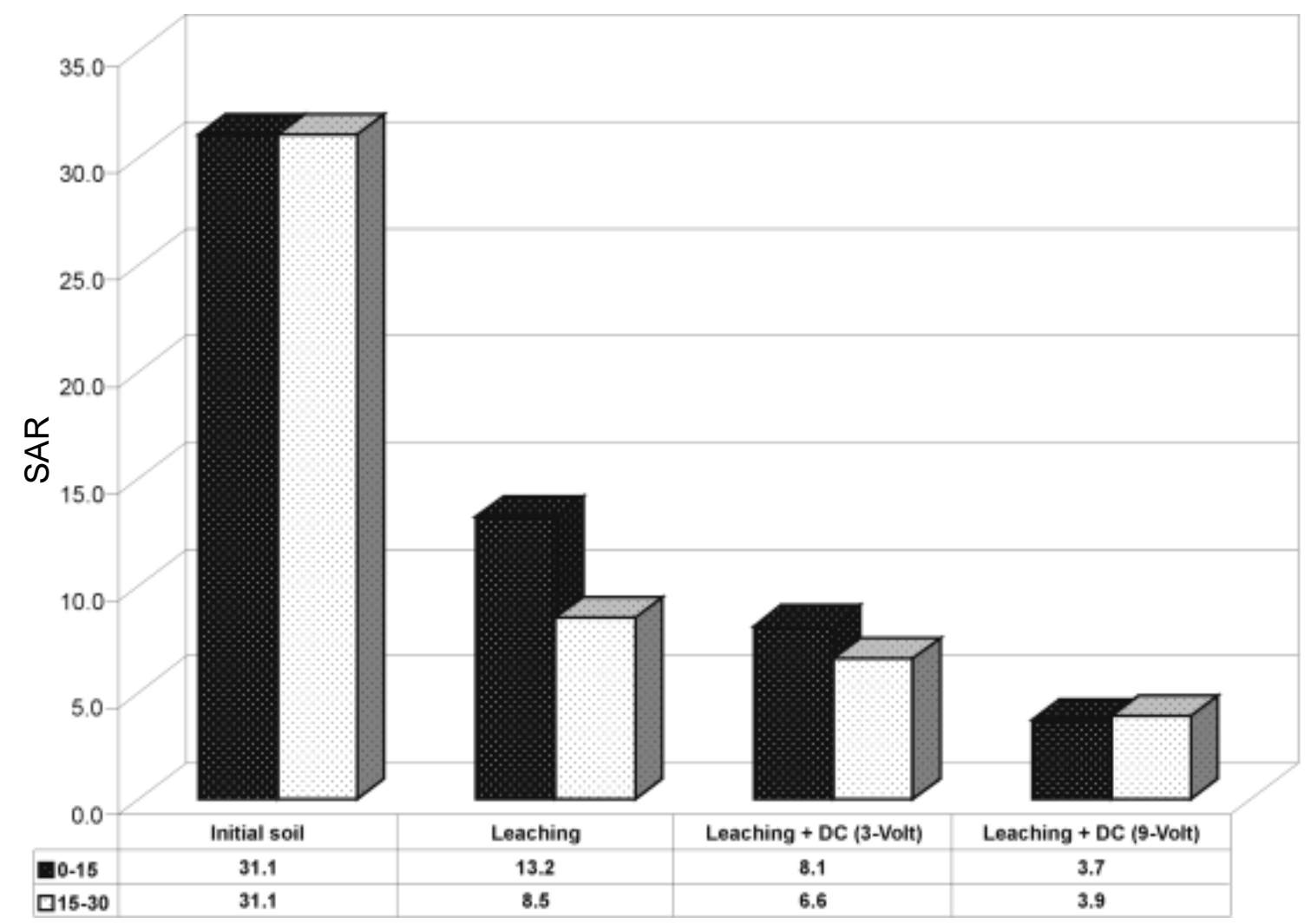

FIGURE 5. SAR in the soil segments after termination of experiment

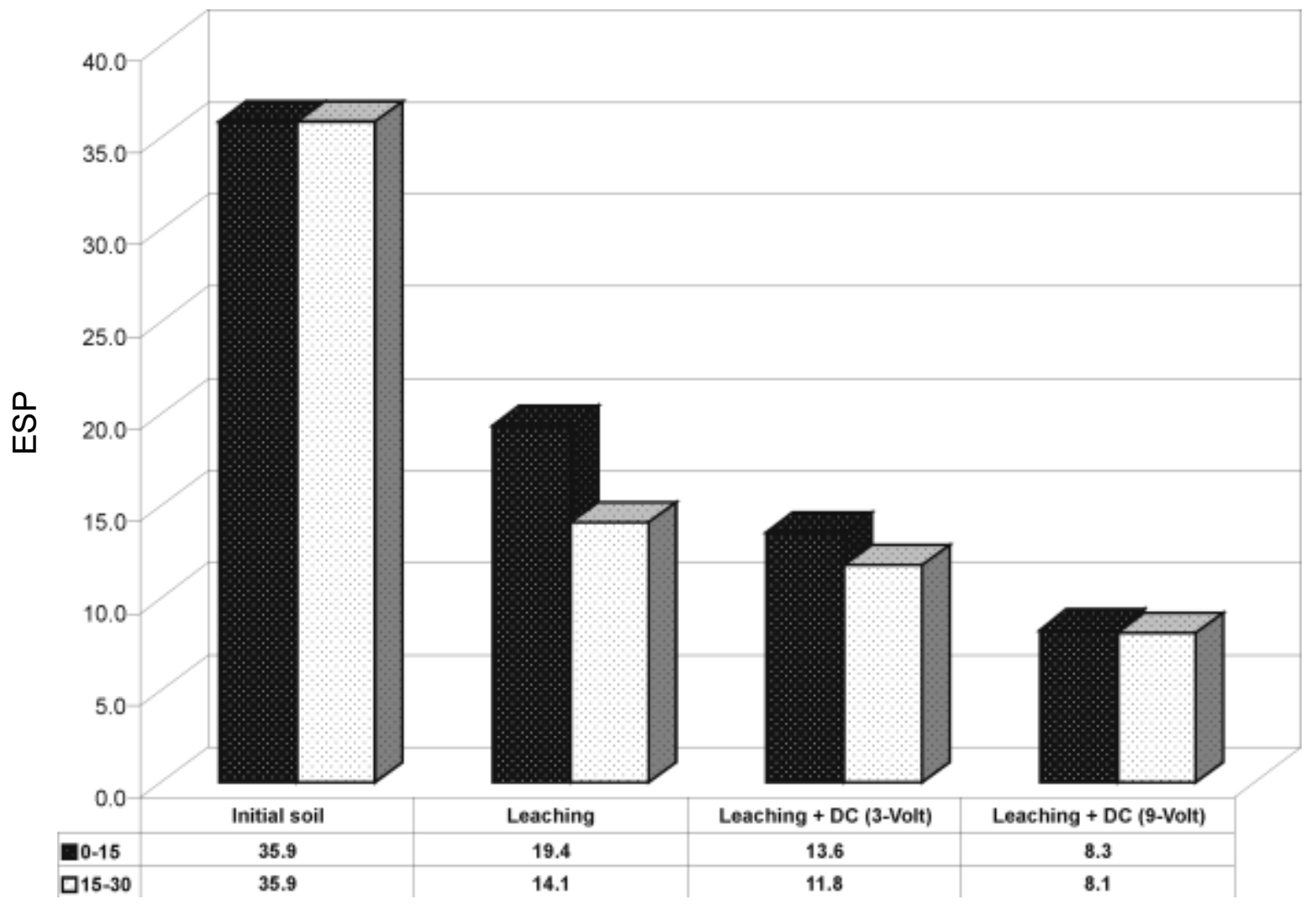

FIGURE 6. ESP [\%] in the soil segments after termination of experiment 


\section{REFERENCES}

Acar Y.B., Alshawabkeh A.N., 1993. Principles of electrokinetic remediation. Environmental Science \& Technology, 27: 2638-2647.

Acar Y.B., Gale R.J., Alshawabkeh A.N., Marks R.E., Puppala S., Bricka M., Parker R., 1995. Electrokinetic remediation: Basics and technology status. Journal of Hazardous Materials, 40: 117-137.

Altaee A., Smith R., Mikhalovsky S., 2008. The feasibility of decontamination of reduced saline sediments from copper using the electrokinetic process. Journal of Environmental Management, 88: 1611-1618.

Amrate S., Akretche D.E., Innocent C., Seta P., 2005. Removal of $\mathrm{Pb}$ from a calcareous soil during EDTA-enhanced electrokinetic extraction. Science of the Total Environment, 349: 56-66.

Athmer C., Ruef C., Jones T., Wilkens R., 2013. Desalinization of kaolin soil using radial electromigration and electroosmosis. Journal of Hazardous, Toxic, and Radioactive Waste, 17(1): 16-20.

Baek K., Kim D.H., Park S.W., Ryu B.G., Bajargal T., Yang J.S., 2009. Electrolyte conditioning-enhanced electrokinetic remediation of arsenic-contaminated mine tailing. Journal of Hazardous Materials, 161: 457-462.

Cho J.M., Kim D.H., Yang J.S., Baek K., 2011. Electrokinetic restoration of sulfate-accumulated saline greenhouse soil. Clean - Soil, Air, Water, 39 (12): 1036-1040.

Cho J.M., Kim K.J., Chung K.Y., Hyun S., Baek K., 2009. Restoration of saline soil in cultivated land using electrokinetic process. Separation Science and Technology, 44: 2371-2384.

De Gioannis G., Muntoni A., Polettini A., Pomi R., 2007. Electrokinetic treatment of marine sediments contaminated by heavy metals. Proceedings of the 23rd Annual Conference on Soils, Sediments and Water, 15-18 October 2007, Amherst, MA, USA.

Eid N., Slack D., Larson D., 2000a. Nitrate electromigration in sandy soil: closed system response. Journal of Irrigation and Drainage Engineering, 126: 389-397.

Eid N., Elshorbagy W., Larson D., Slack D., 2000b. Electro-migration of nitrate in sandy soil. Journal of Hazardous Materials, 79: 133-149.

Jayasekera S., Hall S., 2007. Modification of the properties of salt affected soils using electrochemical treatments. Geotechnical and Geological Engineering, 25: 1-10.

Jia X., Larson D., Slack D., Walworth J., 2005. Electrokinetic control of nitrate movement in soil. Engineering Geology, 77: 273-283.

Jia X., Larson D.L., Zimmt W.S., 2006. Effective nitrate control with electrokinetics in sand soil. Transactions of the ASAE, 49: 803-809.

Kim D.H., Cho J.M., Kitae B., 2011. Pilot-scale ex situ electrokinetic restoration of saline Green house soil. Journal of Soils and Sediments, 11: 947-958.

Kim D.H., Jeon C.S., Baek K., Ko S.H., Yang J.S., 2009a. Electrokinetic remediation of fluorine-contaminated soil. Conditioning of Anolyte. Journal of Hazardous Materials, 161(1): 565-569.

Kim D.H., Ryu B.G., Park S.W., Seo C.I., Baek K., 2009b. Electrokinetic remediation of $\mathrm{Zn}$ and Ni-Contaminated soil. Journal of Hazardous Materials, 165: 501-505.
Kim J.H., Han S.J., Kim S.S., Yang J.W., 2006. Effect of soil chemical properties on the remediation of phenanthrene-contaminated soil by electrokinetic-Fenton process. Chemosphere, 63: 1667-1676.

Kim S.S., Kim J.H., Han S.J., 2005. Application of the electrokinetic-Fenton process for the remediation of kaolinite contaminated with phenanthrene. Journal of Hazardous Materials, 118: 121-131.

Lynch R.J., Muntoni A., Ruggeri R., Winfield K.C., 2007. Preliminary tests of an electrokinetic barrier to prevent heavy metal pollution of soils. Electrochimica Acta, 52: 3432-3440.

Manokararajah K., Sri Ranjan R., 2005a. Electrokinetic denitrification of nitrates in a nitrate contaminated silty loam soil. Applied Engineering in Agriculture, 21(3): 541-549.

Manokararajah K., Sri Ranjan R., 2005b. Electrokinetic retention, migration and remediation of nitrates in silty loam soil under hydraulic gradients. Engineering Geology, 77(3-4): 263-272.

Mitchell J.K., 1993. Fundamentals of soil behavior. $2^{\text {nd }}$ ed., John Wiley and Sons Inc., New York, NY, USA: 437 pp.

Niroumand H., Nazir R., Kassim K.A., 2012. The performance of electrochemical remediation technologies in soil mechanics. International Journal of Electrochemical Science, 7: 5708-5715.

Park J.Y., Kim S.J., Lee Y.J., Baek K., Yang J.W., 2005. EKFenton process for removal of phenanthrene in a two-dimensional soil system. Engineering Geology, 77: 217-224.

Park S.W., Lee J.Y., Yang J.S., Kim K.J., Baek K., 2009. Electrokinetic remediation of contaminated soil with waste-lubricant oils and zinc. Journal of Hazardous Materials, 169: 1168-1172.

Reddy K.R., Chinthamreddy S., 2004. Enhanced electrokinetic remediation of heavy metals in glacial till soils using different electrolyte solutions. Journal of Environmental Engineering, 130: 442-455.

Ryu B.G., Park S.W., Baek K., Yang J.S., 2009. Pulsed electrokinetic decontamination of agricultural lands around abandoned mines contaminated with Heavy Metals. Separation Science and Technology, 44: 2421-2436.

Richards L.A. (ed.), 1954. Diagnosis and improvement of saline and alkali soils. Agriculture Hand Book No. 60 US Gov. Printing Office, Washington, $160 \mathrm{pp}$.

Virkutyte J., Sillanpää M., Latostenmaa P., 2002. Electrokinetic soil remediation - critical overview. The Science of the Total Environment, 289: 97-121.

Van Reeuvijk L.P. (ed.). 2002. Procedures for Soil Analysis. ISRIC, Wageningen.

You-Jin L., Jeong-Hee C., Hyun-Goo L., Tae-Hyun H., 2013. Electrokinetic remediation of saline soil using pulse power. Environmental Engineering Science, 30(3): 133 pp.

Yu J.W., Neretnieks I., 1997. Theoretical evaluation of a technique for electrokinetic decontamination of soils. Journal of Contaminant Hydrology, 26: 291-299.

Zhou D.M., Deng C.F., Cang L., Alshawabkeh A.N., 2005. Electrokinetic remediation of a $\mathrm{Cu}-\mathrm{Zn}$ contaminated red soil by controlling the Volt age and conditioning catholyte $\mathrm{pH}$. Chemosphere, 61: 519-527.

Received: March 6, 2014

Accepted: May 29, 2014 